\title{
Analisis Faktor-Faktor yang Mempengaruhi Jumlah Deposito Mudharabah pada Bank Syariah Mandiri yang Terdaftar di Bank Indonesia Periode 2010-2014
}

Imam Abrori ${ }^{1}$, Siti Khobsoh ${ }^{2}$

Prodi Manajemen, STIE Widya Gama Lumajang ${ }^{1}$, Fakultas Ekonomi, Universitas Muhammadiyah Jember $^{2}$

ari.abrorii@gmail.com

\begin{abstract}
Abstrak
Penelitian ini bertujuan untuk mengetahui dan menjelaskan bagaimana pengaruh Tingkat Inflasi, Tingkat Suku Bunga Deposito, dan Finance to Deposit Ratio terhadap Jumlah Deposito Mudharabah yang ada di bank syariah. Metode penelitian yang digunakan adalah regresi linier berganda. Objek penelitian yang digunakan dalam penelitian ini adalah PT. Bank Syariah Mandiri dengan menggunakan data sekunder berupa laporan publikasi keuangan bulanan yang dimulai dari tahun 2010-2014. Hasil penelitian ini menunjukkan bahwa : Tingkat Inflasi mempunyai pengaruh yang negatif dan signifikan terhadap Jumlah Deposito Mudharabah. Selanjutnya hasil lain diperoleh bahwa Tingkat suku bunga tidak berpengaruh secara positif dan signifikan terhadap Jumlah Deposito Mudharabah. Sedangkan pada hasil Finance to Deposit Ratio mempunyai pengaruh yang positif dan signifikan terhadap Jumlah Deposito Mudharabah. Pengujian ini dilakukan dengan tingkat signifikansi $\alpha=0,1$.
\end{abstract}

Kata kunci: Tingkat Inflasi, Tingkat Suku Bunga, Finance to Deposit Rati, dan Jumlah Deposito Mudharabah.

\begin{abstract}
This study aims to identify and explain how the effect Inflation, Interest Rate Deposit, and Finance to Deposit Ratio Total Mudharabah deposits in Islamic banks. The method used is multiple linear regression. The object of research used in this research is PT. Bank Syariah Mandiri using secondary data from the publication of monthly financial statements starting from 2010-2014. The results showed that: The rate of inflation has a negative and significant effect on the amount of deposits Mudharabah. Furthermore, other results showed that the rate of interest did not affect positively and significantly to Total Deposit Mudharabah. While the results of Finance to Deposit Ratio has positive and significant influence on the amount of deposits Mudharabah. The test is performed with a significance level $\alpha=0.1$.
\end{abstract}

Keywords: Inflation, Interest Rate, Finance to Deposit Ratio and Total Deposits Mudharabah. 


\section{PENDAHULUAN}

Indonesia merupakan salah satu negara berkembang yang saat ini sedang giat membangun dalam usaha untuk mencapai tujuan pembangunan nasional, yang merupakan suatu proses berkelanjutan yang meliputi berbagai bidang yang ditujukan untuk meningkatkan kesejahteraan masyarakat dengan partisipasi aktif serta kerja sama masyarakat, dunia usaha dan pemerintah. Pelaksanaan pembangunan disegala bidang yang berkesinambungan sangat diperlukan untuk mempercepat proses pemulihan perekonomian bagi bangsa Indonesia yang sedang mengalami keterpurukan ekonomi atau yang sering disebut krisis ekonomi.

Menurut Ali (2008), perbankan Islam atau yang sering disebut dengan perbankan syariah merupakan sistem perbankan yang dalam pelaksanaan operasionalnya tidak menggunaknan sistem bunga (riba). Spekulasi (maisi) dan ketidakpastian atau ketidakjelasan (gharar). Perbankan syariah tidak mengenakan konsep bunga dalam operasionalnya, namun bukan berarti iya tidak mengenakan beban pada mereka yang menikmati jasanya. Konsep beban ini merupakan salah satu aktivitas bisnis yang dilakukan perbankan syariah. Bank syariah merupakan bank yang kegiatannya mengacu pada hukum Islam, dan dalam kegiatannya tidak membebankan bunga maupun tidak membayar bunga kepada nasabah. Imbalan yang diterima oleh bank syariah maupun yang dibayarkan kepada nasabah tergantung dari akad dan perjanjian antara nasabah dan bank. Perjanjian (akad) yang terdapat di perbankan syariah harus tunduk pada syarat dan rukun akad sebagimana diatur dalam syariah Islam (Ismail, 2010:32).

Perbankan syariah menjalankan fungsi yang sama dengan perbankan konvensional, yaitu sebagai lembaga intermediasi (penyaluran), dari nasabah pemilik dana (shahibul mal) dengan nasabah yang membutuhkan dana. Namun, dana nasabah dalam bank syariah diperlakukan sebagai investor dan atau penitip dana. Dana tersebut disalurkan perbankan syariah kepada nasabah pembiayaan untuk beragam keperluan, baik produktif (investasi dan modal kerja) maupun konsumtif. Dari pembiayaan tersebut, bank syariah akan memperoleh bagi hasil/marjin yang merupakan pendapatan bagi bank syariah. Jadi, nasabah pembiayaan akan membayar pokok + bagi hasil/marjin kepada Bank Syariah. Pokok akan dikembalikan sepenuhnya kepada nasabah dana sedangkan bagi hasil/marjin akan dibagi hasilkan antara bank syariah dan nasabah dana, sesuai dengan nisbah yang telah disepakati. Artinya dalam bank syariah, dana dari nasabah pendanaan harus di usahakan terlebih dahulu untuk menghasilkan pendapatan. Pendapatan itulah yang akan dibagi hasilkan untuk keuntungan bank syariah dan nasabah dana.

Di perbankan syariah ditekankan kegiatan yang dilakukan bersifat spiritual Jika pada perbankan konvensional, resiko terkait reputasi kepercayaan, dan kerugian pada transaksi keuangan. Sedangkan pada perbankan syariah, selain resiko keuangan, juga ada resiko lain yakni membawa nama syariah dan umat. Sejauh ini memang tidak terlihat persoalan. Tetapi, tetap perlu diingatkan bahwa perbankan konvensional itu hanya resiko transaksi keuangan. Kalau bank syariah ada dua. Ini yang harus hati-hati. Dan beralihnya nasabah dari perbankan konvensional ke syariah merupakan hal yang wajar. Hal ini mengingat nasabah juga memerlukan kepastian keamanan terhadap harta benda yang dimilikinya. Perbankan syariah prinsipnya mengedepankan keseimbangan, tauhid, bebas, dan bertanggung jawab. "Inilah yang menjadi daya tarik perbankan syariah," (Sindo) 
Prinsip kemitraan, saling percaya, dan jujur membuat bank syariah unggul dan mampu melalui setiap krisis moneter. Sistem perbankan syariah belakangan mulai mendapat tempat di hati masyarakat dunia dan kian berkembang pesat. Kehadiran bank-bank syariah itu mampu menjawab kebutuhan akan sistem perbankan yang sesuai syariat Islam. Menurut Pakar ekonomi syariah Syafii Antonio menyatakan paling tidak ada beberapa hal yang membedakan bank syariah dengan bank konvensional. "Yang pertama dari sisi visi dan misinya, kemudian sisi filosofis, struktur organisasinya, legal, produk, laporan keuangan, serta budaya korporasi."

Dominasi PT Bank Syariah Mandiri (BSM) sebagai pemimpin pangsa pasar industri perbankan syariah belum tergoyahkan. Per Desember 2009, anak usaha Bank Mandiri ini menguasai pangsa pasar 33,3\% dari total aset perbankan syariah nasional. Sedangkan dari segi penghimpunan dana pihak ketiga (DPK), BSM menguasai 37\% dan pembiayaan 34,26\%. Per Desember 2009, aset BSM tercatat sebesar Rp 22,03 triliun, DPK Rp 19,33 triliun, dan pembiayaan Rp 16,02 triliun.Untuk periode yang sama, industri perbankan syariah membukukan aset Rp 66,09 triliun, DPK Rp 52,27 triliun, dan pembiayaan Rp 46,88 triliun. Direktur Utama BSM Yuslam Fauzi mengatakan, pihaknya terus memfokuskan bisnis ke sektor ritel. Hal ini terlihat dari porsi dana dan pembiayaan ritel per akhir 2009 yang mencapai 61,6\% dan 60,95\%.

Masyarakat atau perusahaan sebagai pemilik dana mempunyai suatu keinginan, agar dana yang ada dapat berkembang. Bertambahnya nilai suatu dana merupakan suatu perkembangan yang diinginkan oleh para pemilik dana baik dalam jangka pendek maupun untuk masa yang akan datang. Kegiatan menghimpun dan menyalurkan dana merupakan kegiatan pokok bank sedangkan memberikan jasa bank lainnya hanya kegiatan pendukung. Kegiatan penghimpun dana, berupa mengumpulkan dana dari masyarakat dalam bentuk simpanan giro, tabungan, dan deposito. Bank merupakan sarana yang memudahkan aktivitas masyarakat untuk menyimpan uang, dalam hal perniagaan maupun untuk investasi masa depan. Dunia perbankan merupakan salah satu institusi yang sangat berperan dalam bidang perekonomian suatu Negara (khususnya dibidang pembiayaan perekonomian). Manfaat perbankan dalam kehidupan sebagai modal investasi, yang berat, transaksi derivative dapat dijadikan sebagai salah satu model berinvestasi.

Mengingat begitu pesatnya perkembangan perbankan syariah dalam satu dekade terakhir, dan banyak produk-produk pembiayaan perbankan syariah di indonesia maka akan menjadi penting untuk mengetahui faktor-faktor yang mempengaruhi jumlah deposito mudharabah. Sedangkan tingkat ketertarikan masyarakat untuk menginvestasikan dananya diperbankan syariah masih jauh lebih rendah dibandingkan dengan diperbankan konvensional. Hal ini juga menjadi salah satu alasan peneliti untuk mencoba melakukan penelitian.

\section{METODE PENELITIAN}

Jenis data yang digunakan dalam penelitian ini ada jenis data kuantitatif. Data kuantitatif adalah data yang berupa angka-angka yang menunjukkan jumlah atau banyaknya sesuatu, yaitu saldo deposito mudharabah. Periode observasi yang dipilih adalah tahun 2010 sampai dengan tahun 2014. Data time series ini merupakan data sekunder, yang diperoleh dari beberapa sumber, yaitu hasil publikasi laporan keuangan distribusi pendapatan Bank Syariah Mandiri periode bulanan 
dan hasil publikasi Bank Indonesia dengan periode bulanan yaitu Statistik Perbankan Indonesia (SPI). Selain itu, data juga diperoleh dari statistik ekonomi dan perdagangan Indonesia yang dipublikasikan oleh Badan Pusat Statistik (BPS). Data sekunder ini diperoleh secara tidak langsung atau melalui media perantara situs resmi Bank Syariah Mandiri, Bank Indonesia, serta Badan Pusat Statistik.

Populasi adalah kelompok elemen yang lengkap, yang biasanya berupa orang, objek, transaksi, atau kejadian di mana kita tertarik untuk mempelajarinya atau menjadi objek penelitian (Kuncoro, 2009 : 118). Populasi dalam penelitian ini adalah semua laporan keuangan PT Bank Syariah Mandiri periode 2010-1014 yang terdaftar di BI. Sampel adalah suatu himpunan bagian (subset) dari unit populasi. Dalam penelitian ini sampel yang di ambil yaitu laporan keuangan PT. Bank Syariah Mandiri yang diterbitkan selama lima tahun berturut-turut. Data yang diambil dalam penelitian ini adalah data sekunder, yaitu data yang diperoleh secara tidak langsung dari perusahaan yang dijadikan unit analisis, dengan teknik sebagai berikut: a. Penelitian kepustakaan (Library Research) yaitu tehnik untuk mendapatkan data sekunder dalam mendapatkan landasan teoritis yang berkaitan dengan judul penelitian, dengan cara membaca, menelaah buku dan berbagai literatur yang berkaitan dengan penelitian. b. Penelitian melalui situs internet, digunakan untuk melengkapi data sekunder yang telah diperoleh.

Metode analisis yang digunakan dalam penelitian ini adalah analisis regresi linier berganda. Analisis ini bertujuan untuk memperoleh gambaran yang meyeluruh mengenai hubungan antara variabel independen dan variabel dependen. Untuk membuktikan secara empiris dan menganalisis hubungan tersebut diperlukan metode analisis perhitungan dan pengujian sebagai berikut: Uji normalitas bertujuan untuk menguji apakah dalam model regresi, variabel pengganggu atau residul memiliki distribusi normal. Pendeteksian dilakukan dengan cara melihat penyebaran data (titik) pada sumbu diagonal dari grafik dengan dasar pengambilan keputusan: 1 . Jika data menyebar disekitar garis diagonal dan mengikuti arah garis diagonal atau grafik histogramnya menunjukkan pola distribusi normal, maka model regresi memenuhi asumsi normalitas . 2. Jika data menyebar jauh dari diagonal dan/atau tidak mengikuti arah garis diagonal atau grafik histogram tidak menunjukkan pola distribusi normal, maka model regresi tidak memenuhi asumsi normalitas.

Data yang digunakan dalam penelitian berdistribusi normal sehingga uji hipotesis yang digunakan adalah uji analisis regresi linier berganda. Menuru Ghozali (2013) Analisis linier regresi berganda digunakan untuk menguji pengaruh antara variable independen yaitu tingkat inflasi (TI), tingkat suku bunga (TSB), dan tingkat likuiditas (FDR) terhadap jumlah deposito mudharabah (JDM) sebagai variabel dependen. Rumus perhitungan analisis regresi berganda yaitu: JDM $=\alpha+\beta_{1} \mathrm{TI}+\beta_{2} \mathrm{TSB}+\beta_{3} \mathrm{FDR}+\mathrm{e}$ 


$\begin{array}{ll}\text { Keterangan: } & \\ \text { JDM } & =\text { Nominal saldo deposito mudharabah } \\ \alpha & =\text { Konstanta } \\ \beta 1-\beta 3 & =\text { Koefisien regresi } \\ \text { FDR } & =\text { Finance to Deposit Ratio } \\ \text { TSB } & =\text { Tingkat suku bunga } \\ \text { TI } & =\text { Tingkat inflasi }\end{array}$

Untuk mengetahui apakah model regresi benar-benar menunjukkan hubungan yang signifikan dan representatif, maka model tersebut harus memenuhi asumsi klasik regresi. Uji asumsi klasik yang dilakukan adalah uji heteroskedastisitas, autokorelasi dan multikolinieritas.

Uji heteroskedastisitas bertujuan untuk mengetahui apakah dalam model regresi terjadi ketidaksamaan varian (ragam) dari residual satu pengamatan ke pengamatan lain. Model regresi yang baik adalah tidak terjadi heteroskedasitas (Ghozali, 2013). Cara mendeteksi ada atau tidaknya heteroskedasitas adalah dengan melihat grafik plot antara nilai prediksi variabel dependen dengan residualnya dengan dasar analisis berikut: a. Jika ada pola tertentu, seperti titik-titik yang ada membentuk pola tertentu yang teratur, maka mengindikasikan telah terjadi heteroskedastisitas. b. Jika tidak ada pola yang jelas, serta titik-titik menyebar di atas dan di bawah angka 0 pada sumbu $Y$, maka tidak terjadi heteroskedastisitas.

Ghozali (2013) menyebutkan uji autokorelasi yang dilakukan dalam penelitian ini bertujuan untuk menguji apakah dalam sebuah model regresi linier ada korelasi antara kesalahan pengganggu pada periode $\mathrm{t}$ dengan kesalahan pengganggu pada periode $\mathrm{t}$ dengan kesalahan periode t-1 (sebelumnya). Salah satu cara mendeteksi ada atau tidaknya autokorelasi adalah dengan uji Durbin-Watson dengan ketentuan sebagai berikut :

a. Deteksi autokorelasi positif

Jika $\mathrm{d}<\mathrm{dL}$ maka terdapat autokorelasi positif

Jika d > dU maka tidak terdapat autokorelasi positif

Jika $\mathrm{dL}<\mathrm{d}<\mathrm{dU}$ maka pengujian tidak dapat disimpulkan

b. Deteksi autokorelasi negatif

Jika $(4-d)<$ dL maka terdapat autokorelasi negatif

Jika $(4-d)>d U$ maka tidak terdapat autokorelasi negatif

Jika $\mathrm{dL}<(4-\mathrm{d})<\mathrm{dU}$ maka pengujian tidak dapat disimpulkan

Uji multikolinieritas bertujuan untuk menguji apakah model regresi ditemukan adanya korelasi antar variabel bebas (independen). Model regresi yang baik seharusnya tidak terjadi korelasi di antara variabel independen. Salah satu cara untuk mendeteksi ada atau tidaknya multikolinieritas di dalam model regresi adalah dilihat dari nilai Tolerance dan lawannya Variance Inflation Factor. Nilai yang umum dipakai untuk menunjukkan adanya multikolinieritas adalah nilai Tolerance $=0,10$ atau sama dengan nilai VIF $=10$ (Ghozali, 2013).

Koefisien Determinasi $\left(\mathrm{R}^{2}\right)$ pada intinya mengukur seberapa jauh kemampuan model dalam menerangkan variasi variabel dependen. Nilai $R$ yang kecil berarti kemampuan variabel-variabel 
independen dalam menjelaskan variasi variabel dependen amat terbatas. Nilai yang mendekati satu berarti variabel-variabel independen memberikan hampir semua informasi yang dibutuhkan untuk memprediksi variasi variable dependen (Ghozali, 20013). Hipotesis yang digunakan dalam penelitian ini berkaitan dengan ada atau tidaknya pengaruh variabel independen terhadap variabel dependen.

Menurut Imam Ghozali (2013) menerangkan bahwa uji statistik F pada dasarnya menunjukan apakah semua variabel independen yang dimasukan dalam model mempunyai pengaruh secara bersama-sama (simultan) terhadap variabel dependen. Adapun ketentuan penerimaan atau penolakan hipotesis adalah :

1. Jika $\mathrm{F}_{\text {_hitung }}>\mathrm{F}_{\text {_tabel }}$ atau sig $\mathrm{F}<0,1$, maka $\mathrm{H}_{0}$ ditolak dan $\mathrm{H}_{\mathrm{a}}$ diterima

2. Jika $F_{\text {_hitung }}<\mathrm{F}_{\text {_tabel }}$ atau sig $\mathrm{F}>0,1$, maka $\mathrm{H}_{0}$ diterima dan $\mathrm{H}_{\mathrm{a}}$ ditolak

Uji Signifikan Parameter Individual (Uji Statistik t) Pengujian ini menunjukkan seberapa jauh pengaruh satu variabel independen secara individual dalam menerangkan variasi variabel independen (Ghozali, 2013).

Kriteria pengambilan keputusan uji signifikansi ini adalah:

1. Merumuskan hipotesis

2. Kriteria uji t berdasarkan t_hitung

Jika $t_{\_}$hitung $\leq \mathrm{t} \_$tabel maka $\mathrm{H}_{0}$ diterima dan $\mathrm{H}_{\mathrm{a}}$ ditolak

Jika t_hitung $\geq \mathrm{t} \_$tabel $m a k a \mathrm{H}_{\mathrm{a}}$ diterima dan $\mathrm{H}_{0}$ ditolak

3. Menentukan tingkat signifikansi $(\alpha)$

Tingkat signifikan yang digunakan oleh peneliti adalah $10 \%(0,01)$.

\section{HASIL DAN PEMBAHASAN}

Hasil pengujian koefisien dari analisa linier berganda, menunjukan variabel independen (Tingkat Inflasi, Tingkat Suku Bunga dan Finance to Deposit Ratio) mempunyai pengaruh terhadap variabel dependen Jumlah Deposito Mudharabah pada Bank Syariah Mandiri yang terdaftar di BI. Secara simultan berpengaruh secara bersama-sama dan Secara parsial variabel yang dominan berpengaruh terhadap Jumlah Deposito Mudharabah pada Bank SYARIAH mandiri yang terdaftar di BI adalah variabel Finance to Deposit Ratio.

Hasil pengujian menununjukan bahwa Tingkat Inflasi, Tingkat Suku Bunga dan Finance to Deposit Ratio berpengaruh signifikan terhadap Jumlah Deposito Mudharabah pada Bank Syariah Mandiri yang terdaftar di BI dengan arah positif. Berdasarkan hasil pengujian tersebut, maka dapat disumpulkan bahwa hipotesis yang menyatakan "ada pengaruh Tingkat Inflasi, Tingkat Suku Bunga dan Finance to Deposit Ratio terhadap Jumlah Deposito Mudharabah pada Bank Syariah Mandiri yang terdaftar di BI" adalah diterima. Hal ini mengindifikasi bahwa jika Tingkat Inflasi, Tingkat Suku Bunga dan Finance to Deposit Ratio memiliki nilai positif, maka akan memeberikan pengaruh dalam meningkatkan Jumlah Deposito Mudharabah pada Bank Syariah Mandiri yang terdaftar di BI. 
Variabel tingkat inflasi, tingkat suku bunga BI, dan FDR berpengaruh dan signifikan secara simultan terhadap jumlah deposito mudharabah di Bank Syariah Mandiri. Hal ini ditunjukkan dari nilai Sig-F sebesar 0,005, sehingga nilai signifikansi untuk uji F berada di bawah nilai derajat kesalahan yaitu 0,1 . Penggunaan kedua variabel independen tersebut dalam model regresi dapat digunakan untuk menentukan nilai variabel dependen yaitu jumlah deposito mudharabah.

Sementara nilai koefisien determinasi $\left(\mathrm{R}^{2}\right)$ sebesar 0,202 atau 20,2\% menunjukkan bahwa ketiga variabel independend/bebas yang terdiri dari tingkat inflasi, tingkat suku bunga, dan finance to deposito ratio secara simultan mempunyai pengaruh yang membuat jumlah bagi hasil deposito mudharabah meningkat atau menurun. Artinya secara bersama-sama variabel independend/bebas (tingkat inflasi, tingkat suku bunga, dan finance to deposito ratio) memberikan kontribusi/pengaruh sebesar 20,2\% terhadap jumlah bagi hasil deposito mudharabah. Sedangkan sisanya merupakan pengaruh faktor lain diluar ketiga faktor tersebut, namun juga dapat dipengaruhi oleh variabel-variabel lainnya, seperti halnya penelitian oleh Andriyanti dan Wasilah (2010) yang tidak hanya meneliti tingkat suku bunga dan tingkat inflasi, namun juga meneliti variabel lain seperti ukuran bank dan tingkat bagi hasil.

Bagi hasil yang diberikan kepada nasabah oleh bank merupakan salah satu variabel yang dianggap dapat mempengaruhi jumlah deposito mudharabah pada perbankan syariah. Hal tersebut dikarenakan bahwa ketika nasabah ingin melakukan sebuah investasi pada perbankan atau yang disebut dengan deposito mudharabah, maka nasabah akan melihat dan mempelajari bagaimana sistem keuntungan yang didapatkan oleh nasabah sehingga ekspektasi return yang di dapat nantinya akan sesuai harapan nasabah. Setelah mengetahui bagaimana sistem keuntungan yang ada diperbankan, maka nasabah akan dapat memutuskan untuk melakukan investasi atau tidak. Hal tersebut terjadi karena manusia sejatinya memiliki sifat memili, yang dimana apabila bagi hasil deposito mengalami kenaikan secara signifikan akan mempengaruhi nasabah untuk menambah dananya pada deposito, sedangkan apabila bagi hasil deposito secara beberapa bulan terakhir mengalami penurunan, maka nasabah akan melakukan 2 pilihan yaitu tetap mendepositokan dananya pada perbankan syariah atau berhenti untuk menggunakan jasa perbankan syariah dan/atau berganti pada jasa perbankan konvensioanal, maka hal tersebut akan mempengaruhi jumlah deposito mudharabah.

Penjelasan di atas dijelaskan pada sebuah makalah yang dibuat oleh Khan, pada buku ekonomi makro islam, bahwa permintaan investasi ditentukan oleh tingkat keuntungan yang diharapkan. Apabila tingkat keuntungan yang diharapkan mengalami kenaikan, maka akan meningkatkan tingkat investasi oleh investor. Sebaliknya, apanila tingkat leuntungan yang diharapkan mengalami penurunan, maka akan menurunkan pula tingkat investasi.

Penelitian yang dilakukan menunjuakan, bahwa nilai koefisien variabel tingkat inflasi sebesar 113,512 dengan arah negatif dan hasil pengujian hipotesis telah membuktikan pengaruh tingkat inflasi terhadap jumlah deposito mudharabah memiliki nilai t_hitung $-1,875 \geq-1,296$ dan signifikan $0,066 \geq 0$, 1 ,maka Ha diterima negatif dan Ho ditolak, yang berarti secara parsial variabel tingkat inflasi berpengaruh negatif dan signifikan terhadap jumlah deposito mudharabah 
pada Bank Syariah Mandiri yang terdaftar di BI. T_hitung nilai negatif, semakin besar nilai tingkat inflasi yang dimiliki bank syariah maka akan meningkatkan nilai jumlah deposito mudharabah.

Hal ini mengindikasikan apabila tingkat inflasi naik maka jumlah deposito Mudharabah pada Bank Syariah Mandiri akan mengalami kenaikan juga. Inflasi berhubungan negatif dengan deposito yang dihimpun bank. Hal ini disebakan ketika inflasi mengalami kenaikan, maka para nasabah akan mencairkan dananya untuk mempertahankan tingkat konsumsinya.

Berdasarkan hasil tersebut diketahui bahwa tingkat inflasi berpengaruh negatif dan signifikan terhadap jumlah deposito mudharabah Hasil mendukung menurut penelitian sebelumnya yang dilakukan oleh Ani dan wasilah (2010) "Faktor-faktor yang mempengaruhi jumlah penghimpun dana pihak ketiga (Deposito mudharabah 1 bulan) Bank Muamalat Indonesia (BMI)" menunjukkan hasil bahwa Tingkat Inflasi berpengaruh dan signifikan jumlah deposito mudharabah pada bank muamalat indonesia.

Penelitian yang dilakukan menunjuakan, bahwa nilai koefisien variabel tingkat suku bunga sebesar 34,275 dengan arah positif dan hasil pengujian hipotesis telah membuktikan pengaruh tingkat suku bunga terhadap jumlah deposito mudharabah memiliki nilai t_hitung 1,295 $\leq 1,296$ dan signifikan $0,201 \geq 0,1$, maka Ho diterima dan Ha ditolak, yang berarti secara parsial variabel tingkat suku bunga tidak berpengaruh secara positif dan signifikan terhadap jumlah deposito mudharabah pada Bank Syariah Mandiri yang terdaftar di BI. Nilai t_hitung positif, semakin kecil nilai tingkat suku bunga BI maka akan menaikkan nilai jumlah deposito mudharabah.

Hal ini berarti perubahan yang terjadi pada suku bunga deposito bank umum tidak mempengaruhi jumlah deposito mudharabah bank syariah di PT. Bank Syariah Mandiri. Faktor yang menyebabkan suku bunga deposito bank umum tidak berpengaruh terhadap jumlah simpanan deposito mudharabah bank syariah di Bank Syariah Mandiri kemungkinan dipengaruhi karena situasi ekonomi yang sedang baik sehingga akan lebih menguntungkan jika dananya dipergunakan untuk bisnis daripada hanya ditanamkan dalam bentuk deposito. Karena tentunya masyarakat akan lebih memilih yang lebih menguntungkan.

Berdasarkan hasil tersebut diketahui bahwa tingkat suku bunga berpengaruh secara positif dan signifikan terhadap jumlah deposito mudharabah, hasil tidak mendukung penelitian yang dilakukan oleh Desy (2015) "Pengaruh bagi hasil dan suku bunga terhadap jumlah deposito mudharabah" menunjukkan hasil bahwa tingkat suku bunga berpengaruh negatif terhadap jumlah deposito mudharabah.

Penelitian yang dilakukan menunjuakan, bahwa nilai koefisien variabel finance to deposit ratio (FDR) sebesar 13,463 dengan arah positif dan hasil pengujian hipotesis telah membuktikan pengaruh finance to deposit ratio (FDR) terhadap jumlah deposito mudharabah memiliki nilai $\mathrm{t}$ hitung 3,054 $\geq 1,296$ dan signifikan $0,003 \leq 0,1$, maka Ha diterima dan Ho ditolak, yang berarti secara parsial variabel finance to deposit ratio (FDR) berpengaruh positif dan signifikan terhadap jumlah deposito mudharabah pada bank syariah mandiri yang terdaftar di BI. Nilai t_hitung 
positif, semakin besar nilai finance to depoit ratio (FDR) yang dimiliki bank syariah maka akan meningkatkan nilai jumlah deposito mudharabah.

Rasio ini menunjukkan seberapa besar kemampuan bank dalam membayar kembali penarikan dana yang dilakukan deposan dengan mengandalkan kredit yang diberikan sebagai sumber likuiditasnya. Semakin tinggi rasio ini, maka semakin rendah pula kemampuan likuiditas bank tersebut jika ada deposan menarik dananya sehingga kemungkinan suatu bank dalam kondisi bermasalah akan semakin besar. Hal ini akan turut mempengaruhi deposan dalam memilih dimana akan menghimpun dananya.

Berdasarkan hasil tersebut diketahui bahwa finance to deposit ratio (FDR) berpengaruh positif dan signifikan terhadap jumlah deposito mudharabah, hasil tidak mendukung penelitian yang dilakukan oleh Ani dan Wasilah (2010) "Faktor-faktor yang mempengaruhi jumlah penghimpun dana pihak ketiga (Deposito mudharabah 1 bulan) Bank Muamalat Indonesia (BMI)" menunujukan pengaruh negatif finance to deposit ratio (FDR) terhadap jumlah deposito mudharabah.

\section{KESIMPULAN}

Berdasarkan hasil anlisis data yang telah dilakukan peneliti, maka dapat ditarik kesimpulan sebagai berikut: 1) Hasil pengujian hipotesis variabel tingkat inflasi, tingkat suku bunga BI, dan FDR berpengaruh dan signifikan secara simultan terhadap jumlah deposito mudharabah. 2) Hasil pengujian hipotesis telah membuktikan terdapat pengaruh negatif dan signifikan tingkat inflasi terhadap jumlah deposito mudharabah secara parsial. 3) Hasil pengujian hipotesis telah membuktikan tidak terdapat pengaruh secara positif dan signifikan tingkat suku bunga terhadap jumlah deposito mudharabah secara parsial. 4) Hasil pengujian hipotesis telah membuktikan terdapat pengaruh positif dan signifikan finance to deposit ratio (FDR) terhadap jumlah deposito mudharabah secara parsial. Berdasarkan kesimpulan yang telah dikemukakan di atas, maka saran yang diajukan dalam penelitian ini adalah untuk penelitian selanjutnya, sebaiknya mempertimbangkan waktu pengamatan yang lebih lama sehingga diharapkan akan mendapat hasil penelitian yang lebih akurat. Menggunakan variabel-variabel yang belum disebutkan dalam penelitian ini, sehingga dapat memperoleh hasil penelitian yang lebih baik lagi.

\section{DAFTAR PUSTAKA}

Ali, Z. (2008). Hukum Perbankan Syariah. Jakarta : Sinar Grafika

Almilia, L. S. \& Utomo, A. W. (2006). Faktor-Faktor Yang Mempengaruhi Tingkat Suku Bunga Deposito Berjangka Pada Bank Umum Di Indonesia. Jurnal Ekonomi Dan Bisnis Antisipasi. STIE Perbanas Surabaya

Andriyanti, A. \& Wasilah. (2010). Faktor-Faktor Yang Mempengaruhi Jumlah Penghimpunan Dana Pihak Ketiga. Simposium Nasional Akuntansi XIII.

Anjani, B. B. (2012). Analisis Faktor-Faktor Yang Berpengaruh Terhadap Keputusan Investasi Pada Perusahaan Food And Beverages Di Bursa Efek Indonesia. Skripsi ,Universitas Diponegoro Semarang 
Antonio, M. S. (2001). Bank Syariah Dari Teori Ke Praktik. Jakarta: Gema Insani Press.

Arif, F. M., Abrori, I., Rosyadi, I. N. (2017). Pengaruh Budaya Organisasi dan Gaya Kepemimpinan Terhadap Komitmen Organisasi Pengurus Pondok Pesantren Mahasiswa AlJauhar Sumbersaei Jember. Prosiding Seminar Nasional dan Call For Paper Ekonomi dan Bisnis (SNAPER-EBIS 2017). 326-338

Badan Penerbit Universitas Muhammadiyah Jember. (2014). Pedoman Penelitian Skripsi; Fakultas Ekonomi. Universitas Muhammadiyah Jember

Bank Indonesia. Statistik Perbankan Syariah Indonesia. Diakses dari bi.go.id

Budiati, A. N. (2007). Pengaruh Tingkat Suku Bunga Dan Tingkat Bagi Hasil Terhadap Pendanaan Pada Bank Muamalat Indonesia. Skripsi.Universitas Indonesia

Cahyono, A. (2009). Pengaruh Indikator Makroekonomi Terhadap Dana Pihak Ketiga Dan Pembiayaan Bank Syariah Mandiri. Tesis. Universitas Indonesia

Elionasari, N. P. (2008). Analisis Perbandingan Tingkat Kinerja Keuangan Bank Syariah \& Bank Konvensional. Skripsi. Universitas Lampung

Fahmi, I. (2006). Analisis Investasi Dalam Perspektif Ekonomi Dan Politik. Bandung.PT Revika Aditama

Ghozali, I. (2013). Aplikasi Analisis Multivariate dengan Program IBM SPSS 21. Edisi Ketujuh. Semarang: Badan Penerbit Universitas Diponegoro

Harmono, (2009). Manajemen Keuangan. Cetakan Pertama, Penerbit Bumi Aksara, Yogyakarta.

Ismail. (2011). Perbankan Syariah. Jakarta:Prenada Media Grup

Komaruddin. (2004). Uang Di Negara Sedang Berkembang. Bumi Aksara

Martono, A. H. (2005). Manajemen Keuangan. Edisi Pertama Cetakan Kelima, EKONISIA, Yogyakarta

Nufus, H. (2004). Faktor-Faktor Yang Mempengaruhi Penghimpunan Dana Pihak Ketiga. Tesis. Universitas Indonesia

Nurdin, R. (2004). Analisis Faktor Jumlah Uang Beredar Terhadap Jumlah Dana Deposito Masyarakat Pada Bank Syariah. Tesis. Universitas Indonesia

Pariyo. (2004). Variabel Makro Ekonomi Yang Mempengaruhi Penghimpunan Dana Pihak Ketiga. Tesis. Universitas Indonesia

Pratasari, Y. (2010). Faktor-Faktor Yang Mempengaruhi Simpanan Deposito Pada Bank Syariah Bank Konvensional Di Indonesia. Tesis. Universitas Indonesia

Purniawan, E. (2014). Faktor-Faktor Yang Mempengaruhi Jumlah Penghimpun Dana Pihak Ketiga (Deposito Mudharabah) Pada Bank Pembiayaan Rakyat Syariah di Indonesia. Skripsi . Universitas Islam Negeri Sunan Kalijaga Yogyakarta

Subramanyam, K. R. \& John, J. W. (2010). Analisis Laporan Keuangan. Jakarta: 30 Salemba Empat

Sukirno, S. (2004). Makro Ekonomi Modern. Jakarta: Raja Grafindo Pustaka

Sumar'in. (2012). Konsep Kelembagaan Bank Syariah. Yogyakarta : Graha Ilmu

Sutrisno, (2000). Manajemen Keuangan Modern. Bumi Aksara, Jakarta.

Suyatno, T. (2007). Kelembagaan Perbankan. Jakarta: Gramedia PustakaUtama

Wiroso. (2009). Produk Perbankan Syariah. Jakarta: LPFE Usakti.

Wulansari, D. I. (2015). Pengaruh Bagi Hasil Dan Suku Bunga Terhadap Jumlah Deposito Mudharabah. Jurnal Ilmiah. Universitas Brawijaya Malang

http://www.simulasikredit.com/cara-menghitung-bunga-efektif/ 